\title{
Heat transfer from oriented heat exchange areas
}

\author{
Martin Vantuch ${ }^{1}$, Jozef Huzvar ${ }^{1}$, Andrej Kapjor ${ }^{1}$, \\ ${ }^{1}$ University of Žilina, Faculty of Mechanical Engineering, Department of power engineering - Univerzitná 1, 010 26, \\ Žilina, Slovak Republic
}

\begin{abstract}
This paper deals with the transfer of heat-driven heat transfer surface area in relation to the construction of the criterion equation for " $n$ " horizontal pipe one about another. On the bases of theoretical models have been developed for calculating the thermal performance of natural convection by Churilla and Morgan, for various pipe diameters and temperatures. These models were compared with models created in CFD-Fluent Ansys the same boundary conditions. The aim of the analyse of heat and fluxional pipe fields „n“ pipes one about another at natural convection is the creation of criterion equation on the basis of which the heat output of heat transfer from pipe oriented areas one above another with given spacing could be quantified. At presence a sum of criterion equations exists for simple geometrical shapes of individual oriented geometrical areas but the criterion equation which would consider interaction of fluxional field generated by free convection from multiple oriented areas is not mentioned in standardly accessible technical literature and other magazine publications.
\end{abstract}

\section{Introduction}

Creation of criterion equation for calculation of heat output is signified for quantification of heat outputs calculations of geometrically more complicated heat transfer areas in engineering praxis and furthermore for optimization of processes such as schemes of pipe heat bodies and many other applications in technical praxis that are related to heat transfer by free convection. The process of finding a new criterion equation for above mentioned geometries was carried out on the basis of numerical experiment by simulation of heat transfer for various thermo-kinetic and geometrical parameters of pipe alignment one above another. Some simulations were verified by measuring of output of real pipe system in specialized thermostatic chamber. Used numeric model of CFD method was validated by this way.

On the basis of this comparison where equalities will be gained in calculated and modelled results, models will be created in the programme Ansys-Fluent for „n“ horizontal pipes one above another.

Data from this program and famous criterion equation for one pipe will be used to create criterion relation to

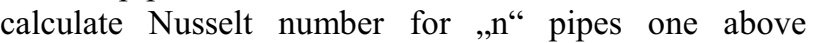
another. A criterion relation for calculating Nusselt number according to Morgan [1] will be used on the basis of analyses of heat transfer of one horizontal pipe.

\section{Materials and Methods}

Modelling of output parameters of one horizontal pipe at natural convection was carried out both in programme Ansys 13 - Workbench as well as by using known criterion equations of similarity theory for one horizontal pipe. Numeric modelling was carried out with the aim to verify both methods of calculating output parameters at natural convection of one horizontal pipe. Mentioned verification enabled us relevant using of programme Ansys 13 - Workbench to gain wide database of heat outputs of explored pipe system by various thermo-kinetic parameters and heat transfer area geometry and as well as by creating of criterion equation for natural convection of „n“

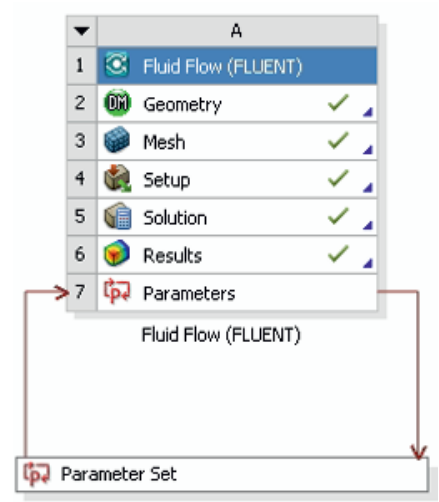

Figure 1. The basic scheme of calculation

\footnotetext{
${ }^{\mathrm{a}}$ Corresponding author: martin.vantuch@fstroj.uniza.sk
} 
To compare mathematical model created on the basis of criterion equations and by a calculation in the programme Ansys 13 - Workbench, comparations of calculated output parameters of natural convection of horizontal pipe were created. In both examples more simulations were carried out whose results are given in following tables or graphs with simulated pipes with mostly used diameter $15-66 \mathrm{~mm}$, at pipe temperatures $30^{\circ} \mathrm{C}-105^{\circ} \mathrm{C}$ and at a surrounding temperature $20^{\circ} \mathrm{C}$.

The basic procedure scheme analysis of heat transport from horizontal pipe by natural convection is shows in Figure 1. To visualize the temperature field and also for the calculation of performance characteristics was necessary to create the geometry of heat transfer from horizontal pipe by natural convection (the application storage tubes in unbounded space was used) in the first step.

For a long horizontal cylinder (pipe, heat pipe exchanger...) as a characteristic diameter is the outer diameter of pipe. According to Morgan [1] is the simply relation for determine the mean Nusselt number:

$$
\overline{N u}_{d}=\frac{\bar{\alpha} d}{\lambda}=C R a_{d}^{n}
$$

where the multiple article $\mathrm{C}$ and exponent $\mathrm{n}$ are depended on Rayleigh criteria number in table 1.

Table 1. The basic scheme of calculation

\begin{tabular}{|l|c|l|}
\hline $\mathrm{Ra}_{\mathrm{d}}$ & $\mathrm{C}$ & $\mathrm{n}$ \\
\hline $10^{-10}-10^{-2}$ & 0,675 & 0,058 \\
\hline $10^{-2}-10^{2}$ & 1,02 & 0,148 \\
\hline $10^{2}-10^{4}$ & 0,85 & 0,188 \\
\hline $10^{4}-10^{7}$ & 0,48 & 0,25 \\
\hline $10^{7}-10^{12}$ & 0,125 & 0,333 \\
\hline
\end{tabular}

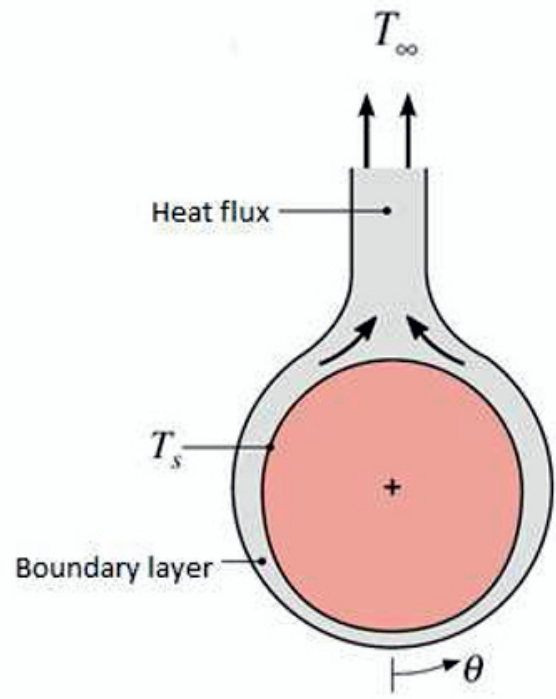

Figure 2. The basic scheme of calculation
Churchill suggests a relation for all range of Rayleigh number (2):

$$
\begin{gathered}
R a_{d}=\frac{g \beta\left(T_{s}-T_{\infty}\right) d^{3}}{v a} \\
N u_{d}=\left\{0,60+\frac{0,387 R a_{d}^{1 / 6}}{\left[1+(0,559 / P r)^{9 / 16}\right]^{8 / 27}}\right\}^{2}
\end{gathered}
$$

\section{Results}

Modelling of heat transfer from horizontal pipe in the programme Ansys 13 - Workbench was carried out in the system of analyses Fluid Flow (Fluent) using the finite volume method. To simplify calculations and in consideration of pipe geometry the 2-D model could be used to calculate heat transfer from horizontal pipe with given parameter, which was a diameter of horizontal pipe. Following boundary conditions of calculation were entered in the program Fluent:

- laminar model of streaming (results from calculation of Rayleig number, for which is the critical value $\mathrm{Ra}_{\text {krit }}=10^{9}$ for laminar streaming)

- $\quad$ pipe's wall temperature - entered as parameter

- boundaring control area for analysing natural convection defined as ,pressure outlet" with given temperature $20^{\circ} \mathrm{C}$ which is $\mathrm{T} \infty=20^{\circ} \mathrm{C}$

- acceleration of gravity $9,80665 \mathrm{~m} \cdot \mathrm{s}^{-2}$

- Boussinesq model of calculating air density, suitable for natural convection (according to Fluent publication)

- under relaxation factors except for energy and pressure decreased on half (according to Fluent publication)

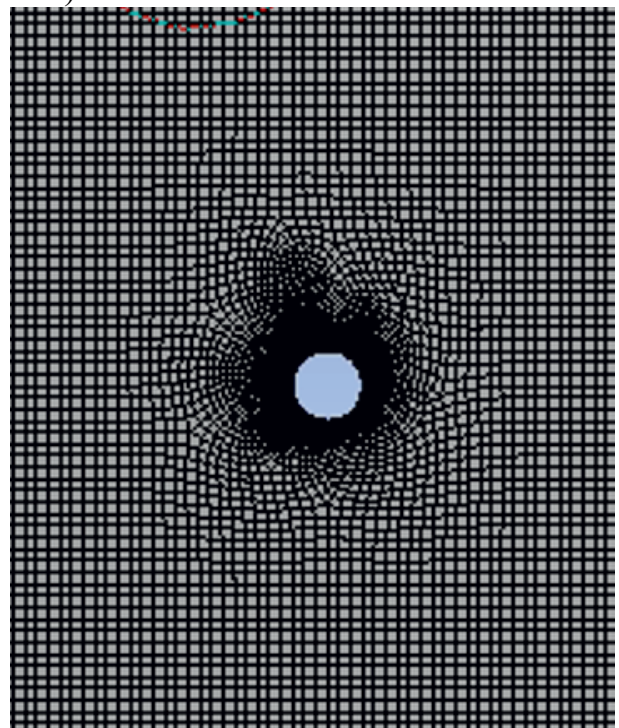

Figure 3. Mathematical mesh of horizontal pipe and surrounding

After the entering the boundary conditions and configurations parameters for parametric analysis was activate the calculation. Programme Ansys Parameters 
was started after the calculation was converged. Eighteen diameters of the horizontal pipes were set (diameters from $16 \mathrm{~mm}$ to $66 \mathrm{~mm}$ ).

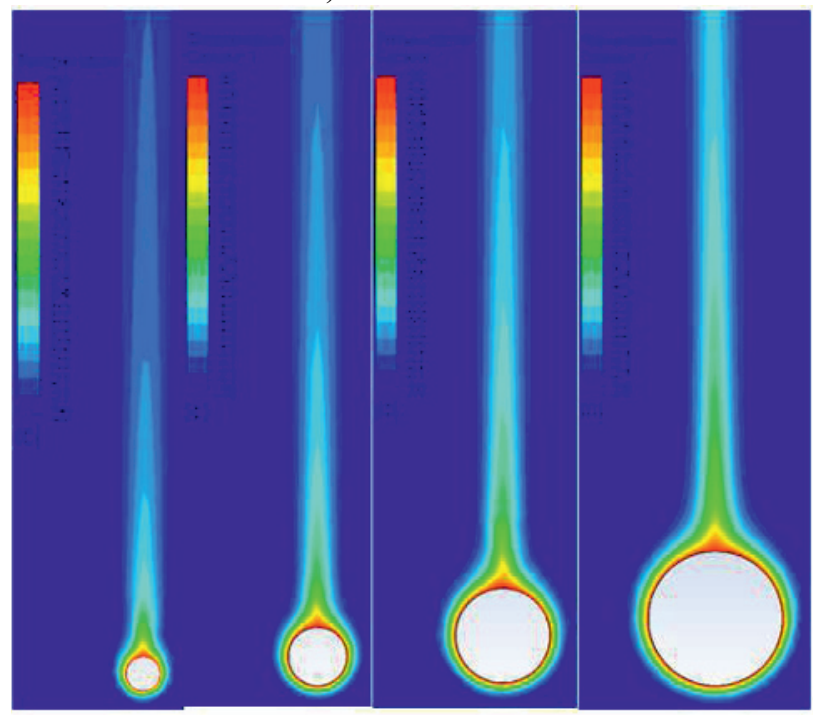

Figure 4. Temperature fields of horizontal pipes with the diameter $15 \mathrm{~mm}, 27 \mathrm{~mm}, 45 \mathrm{~mm}, 66 \mathrm{~mm}$ at wall temperature $30^{\circ} \mathrm{C}$ and at surrounding temperature $20^{\circ} \mathrm{C}$

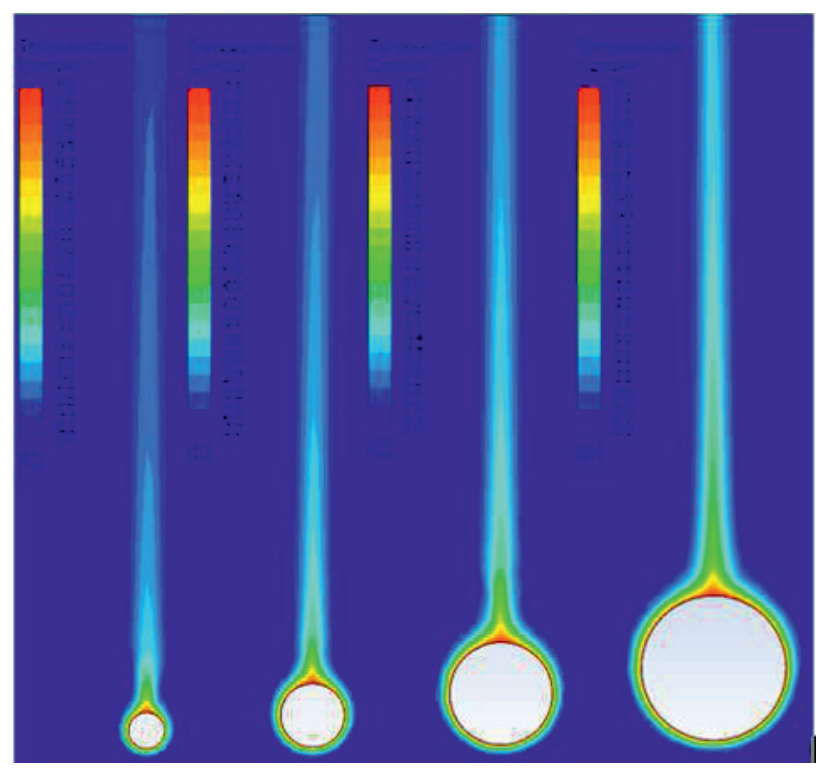

Figure 5. Temperature fields of horizontal pipes with the diameter $15 \mathrm{~mm}, 27 \mathrm{~mm}, 45 \mathrm{~mm}, 66 \mathrm{~mm}$ at wall temperature $75^{\circ} \mathrm{C}$ and at surrounding temperature $20^{\circ} \mathrm{C}$

Temperature fields at natural convection from horizontal pipe are visualized in the Figures 4-6, where pipes with the diameter $15 \mathrm{~mm}, 27 \mathrm{~mm}, 45 \mathrm{~mm}$ and $66 \mathrm{~mm}$ are shown at temperatures $30^{\circ} \mathrm{C}, 45^{\circ} \mathrm{C}, 60^{\circ} \mathrm{C}, 75^{\circ} \mathrm{C}, 90^{\circ} \mathrm{C}$ and $105^{\circ} \mathrm{C}$ and at a surrounding temperature $20^{\circ} \mathrm{C}$. It is evident from these pictures that the diameter of the pipe and its wall temperature highly influences the size and shape of the marginal layer, the geometry of the heat flow behind the pipe and the reach of heaten air above the pipe. The character of streaming by these wall temperatures and diameters is laminar.

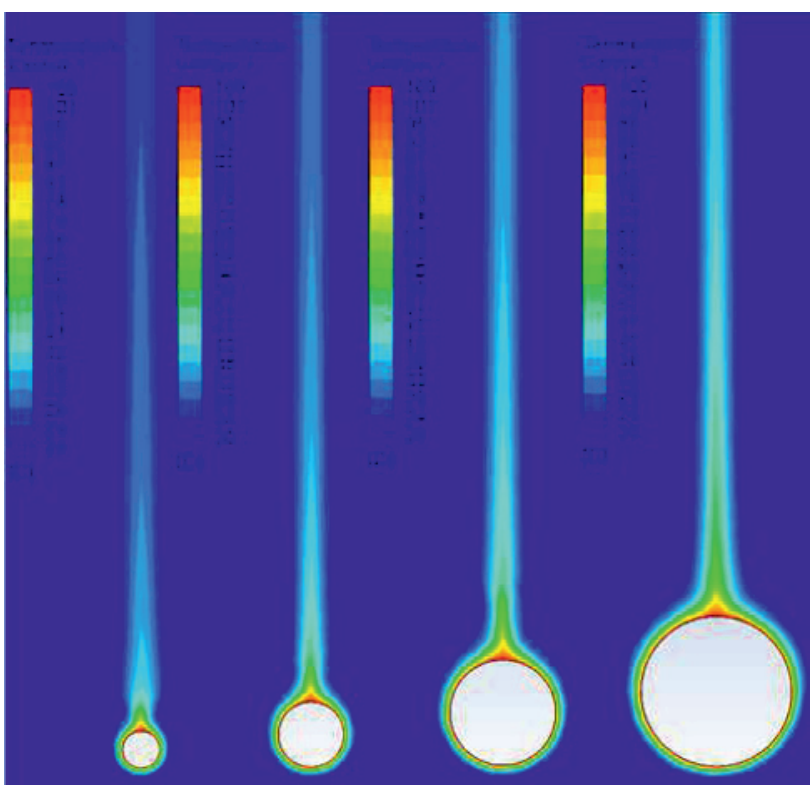

Figure 6. Temperature fields of horizontal pipes with the diameter $15 \mathrm{~mm}, 27 \mathrm{~mm}, 45 \mathrm{~mm}, 66 \mathrm{~mm}$ at wall temperature $105^{\circ} \mathrm{C}$ and at surrounding temperature $20^{\circ} \mathrm{C}$

As the diameter as well as the temperature, as was found out by previous simulations, have a very important influence on the character of the streaming and finally also on transferred output at natural convection two nondimensional parameters were selected $\mathrm{S} / \mathrm{D}$ and $\mathrm{T} \infty / \mathrm{Ts}$, where „S“ is the pipe spacing, „D“ is the pipe diameter, „Tळ" is the surrounding temperature and Ts is the pipe's wall temperature. Heat outputs of horizontal pipe at a wall temperature $30^{\circ} \mathrm{C}, 45^{\circ} \mathrm{C}, 60^{\circ} \mathrm{C}, 75^{\circ} \mathrm{C}, 90^{\circ} \mathrm{C}$ and $105^{\circ} \mathrm{C}$ are shown in the table 2 .

Table 2. Heat outputs of horizontal pipe at a surrounding temperature $20^{\circ} \mathrm{C}$ and at pipe's wall temperatures $30-105^{\circ} \mathrm{C}$

\begin{tabular}{|c|l|l|l|l|l|l|}
\hline Diameters & $\begin{array}{c}30^{\circ} \mathrm{C} \\
\mathrm{Q}[\mathrm{W}]\end{array}$ & $\begin{array}{c}45^{\circ} \mathrm{C} \\
\mathrm{Q}[\mathrm{W}]\end{array}$ & $\begin{array}{c}60^{\circ} \mathrm{C} \\
\mathrm{Q}[\mathrm{W}]\end{array}$ & $\begin{array}{c}75^{\circ} \mathrm{C} \\
\mathrm{Q}[\mathrm{W}]\end{array}$ & $\begin{array}{c}90^{\circ} \mathrm{C} \\
\mathrm{Q}[\mathrm{W}]\end{array}$ & $\begin{array}{c}105^{\circ} \mathrm{C} \\
\mathrm{Q}[\mathrm{W}]\end{array}$ \\
\hline 15 & 3,14 & 9,75 & 17,43 & 25,64 & 33,25 & 43,74 \\
\hline 18 & 3,56 & 11,00 & 19,63 & 29,11 & 39,25 & 49,93 \\
\hline 21 & 3,97 & 12,32 & 22,07 & 32,80 & 44,33 & 56,53 \\
\hline 24 & 4,33 & 13,49 & 24,18 & 35,96 & 48,61 & 62,05 \\
\hline 27 & 4,73 & 14,72 & 26,39 & 39,27 & 52,82 & 67,35 \\
\hline 30 & 5,10 & 15,97 & 28,71 & 42,76 & 57,87 & 73,88 \\
\hline 33 & 5,42 & 16,88 & 30,28 & 45,03 & 60,81 & 77,49 \\
\hline 36 & 5,82 & 18,28 & 32,95 & 49,20 & 66,69 & 85,26 \\
\hline 39 & 6,18 & 19,42 & 34,96 & 52,20 & 70,77 & 90,42 \\
\hline 42 & 6,47 & 20,28 & 36,54 & 54,36 & 73,65 & 94,12 \\
\hline 45 & 6,81 & 21,43 & 38,67 & 57,79 & 78,45 & 100,37 \\
\hline 48 & 7,23 & 22,88 & 41,40 & 62,00 & 84,26 & 107,91 \\
\hline 51 & 7,52 & 23,82 & 43,12 & 64,58 & 87,73 & 112,33 \\
\hline 54 & 7,96 & 25,41 & 46,23 & 69,44 & 94,32 & 121,02 \\
\hline 57 & 8,18 & 25,98 & 47,19 & 70,72 & 96,24 & 123,39 \\
\hline 60 & 8,48 & 26,88 & 48,70 & 72,84 & 98,95 & 126,68 \\
\hline 63 & 8,86 & 28,25 & 51,36 & 77,11 & 104,95 & 134,54 \\
\hline 66 & 9,07 & 28,92 & 52,51 & 78,83 & 107,31 & 137,60 \\
\hline & & & & & & \\
\hline
\end{tabular}


Modelling of heat transport from horizontal pipes at natural convection was carried out also on the basis of criterion equations of similarity theory (relation 1-3).

Table 3 Heat outputs of horizontal pipe at a surrounding temperature $20^{\circ} \mathrm{C}$ and at pipe's wall temperatures $30-105^{\circ} \mathrm{C}$ according to Churchill

\section{Calculation of $\mathrm{Nu}$ according to Churchill relation}

\begin{tabular}{|c|c|c|c|c|c|c|}
\hline $\begin{array}{c}\text { Diameter } \\
{[\mathrm{mm}]}\end{array}$ & $\begin{array}{c}30^{\circ} \mathrm{C} \\
\mathrm{Q} \\
{[\mathrm{W}]}\end{array}$ & $\begin{array}{c}45^{\circ} \mathrm{C} \\
\mathrm{Q}\end{array}$ & $\begin{array}{c}\left.60^{\circ} \mathrm{C}\right] \\
\mathrm{Q} \\
{[\mathrm{W}]}\end{array}$ & $\begin{array}{c}75^{\circ} \mathrm{C} \\
\mathrm{Q} \\
{[\mathrm{W}]}\end{array}$ & $\begin{array}{c}90^{\circ} \mathrm{C} \\
\mathrm{Q} \\
{[\mathrm{W}]}\end{array}$ & $\begin{array}{c}105^{\circ} \mathrm{C} \\
\mathrm{Q} \\
{[\mathrm{W}]}\end{array}$ \\
\hline 15 & 2,75 & 8,55 & 15,41 & 23,05 & 31,32 & 40,15 \\
\hline 18 & 3,11 & 9,74 & 17,61 & 26,37 & 35,87 & 46,02 \\
\hline 21 & 3,47 & 10,91 & 19,75 & 29,62 & 40,33 & 51,78 \\
\hline 24 & 3,82 & 12,05 & 21,86 & 32,82 & 44,72 & 57,44 \\
\hline 27 & 4,16 & 13,18 & 23,94 & 35,97 & 49,04 & 63,03 \\
\hline 30 & 4,5 & 14,29 & 25,99 & 39,08 & 53,32 & 68,55 \\
\hline 33 & 4,84 & 15,39 & 28,02 & 42,16 & 57,55 & 74,02 \\
\hline 36 & 5,17 & 16,47 & 30,03 & 45,21 & 61,74 & 79,44 \\
\hline 39 & 5,49 & 17,55 & 32,02 & 48,24 & 65,9 & 84,82 \\
\hline 42 & 5,82 & 18,62 & 34 & 51,25 & 70,04 & 90,16 \\
\hline 45 & 6,14 & 19,68 & 35,96 & 54,24 & 74,14 & 95,47 \\
\hline 48 & 6,46 & 20,74 & 37,92 & 57,2 & 78,23 & 100,75 \\
\hline 51 & 6,81 & 22,03 & 40,59 & 61,68 & 84,92 & 110,1 \\
\hline 54 & 7,09 & 22,83 & 41,79 & 63,1 & 86,33 & 111,23 \\
\hline 57 & 7,4 & 23,87 & 43,71 & 66,02 & 90,35 & 116,43 \\
\hline 60 & 7,72 & 24,9 & 45,63 & 68,94 & 94,36 & 121,61 \\
\hline 63 & 8,03 & 25,93 & 47,54 & 71,84 & 98,35 & 126,78 \\
\hline 66 & 8,34 & 26,95 & 49,44 & 74,73 & 102,33 & 131,92 \\
\hline
\end{tabular}

This modelling was carried out by same boundary conditions as by modelling in the programme Ansys because of comparing used calculation methods. This means that calculations of outputs were carried out for horizontal pipe diameters from $15 \mathrm{~mm}$ to $66 \mathrm{~mm}$ at a wall temperature $30^{\circ} \mathrm{C}, 45^{\circ} \mathrm{C}, 60^{\circ} \mathrm{C}, 75^{\circ} \mathrm{C}, 90^{\circ} \mathrm{C}, 105^{\circ} \mathrm{C}$ and at a surrounding temperature $20^{\circ} \mathrm{C}$. Heat outputs of horizontal pipe at natural convection calculated with the help of Nuselt number according to Morgan relation [1] as well as according to Churchill relation [2] (relation 13 ). Using two different criterion relations for calculating heat output of horizontal pipe at natural convection was carried out to compare these two relations with calculation in the programme Ansys - Fluent and consequently to choose suitable calculation criterion relation to define the Nuselt number.
Table 4 Heat outputs of horizontal pipe at a surrounding temperature $20^{\circ} \mathrm{C}$ and at pipe's wall temperatures $30-105^{\circ} \mathrm{C}$ according to Morgan

\begin{tabular}{|c|c|c|c|c|c|c|}
\hline \multicolumn{6}{|c|}{ Calculation of Nu according to Churchill relation } \\
\hline $\begin{array}{c}\text { Diameter } \\
{[\mathrm{mm}]}\end{array}$ & $\begin{array}{c}30^{\circ} \mathrm{C} \\
\mathrm{Q} \\
{[\mathrm{W}]}\end{array}$ & $\begin{array}{c}45^{\circ} \mathrm{C} \\
\mathrm{Q} \\
{[\mathrm{W}]}\end{array}$ & $\begin{array}{c}60^{\circ} \mathrm{C} \\
\mathrm{Q} \\
{[\mathrm{W}]}\end{array}$ & $\begin{array}{c}75^{\circ} \mathrm{C} \\
\mathrm{Q} \\
{[\mathrm{W}]}\end{array}$ & $\begin{array}{c}90^{\circ} \mathrm{C} \\
\mathrm{Q} \\
{[\mathrm{W}]}\end{array}$ & $\begin{array}{c}105^{\circ} \mathrm{C} \\
\mathrm{Q} \\
{[\mathrm{W}]}\end{array}$ \\
\hline 15 & 2,75 & 8,55 & 15,41 & 23,05 & 31,32 & 40,15 \\
\hline 18 & 3,11 & 9,74 & 17,61 & 26,37 & 35,87 & 46,02 \\
\hline 21 & 3,47 & 10,91 & 19,75 & 29,62 & 40,33 & 51,78 \\
\hline 24 & 3,82 & 12,05 & 21,86 & 32,82 & 44,72 & 57,44 \\
\hline 27 & 4,16 & 13,18 & 23,94 & 35,97 & 49,04 & 63,03 \\
\hline 30 & 4,5 & 14,29 & 25,99 & 39,08 & 53,32 & 68,55 \\
\hline 33 & 4,84 & 15,39 & 28,02 & 42,16 & 57,55 & 74,02 \\
\hline 36 & 5,17 & 16,47 & 30,03 & 45,21 & 61,74 & 79,44 \\
\hline 39 & 5,49 & 17,55 & 32,02 & 48,24 & 65,9 & 84,82 \\
\hline 42 & 5,82 & 18,62 & 34 & 51,25 & 70,04 & 90,16 \\
\hline 45 & 6,14 & 19,68 & 35,96 & 54,24 & 74,14 & 95,47 \\
\hline 48 & 6,46 & 20,74 & 37,92 & 57,2 & 78,23 & 100,75 \\
\hline 51 & 6,81 & 22,03 & 40,59 & 61,68 & 84,92 & 110,1 \\
\hline 54 & 7,09 & 22,83 & 41,79 & 63,1 & 86,33 & 111,23 \\
\hline 57 & 7,4 & 23,87 & 43,71 & 66,02 & 90,35 & 116,43 \\
\hline 60 & 7,72 & 24,9 & 45,63 & 68,94 & 94,36 & 121,61 \\
\hline 63 & 8,03 & 25,93 & 47,54 & 71,84 & 98,35 & 126,78 \\
\hline 66 & 8,34 & 26,95 & 49,44 & 74,73 & 102,33 & 131,92 \\
\hline & & & & & \\
\hline & & & & \\
\hline
\end{tabular}

Graph 1. Heat output of horizontal pipe at natural convection at the temperature of pipe's wall $30^{\circ} \mathrm{C}$ and at the surrounding temperature $20^{\circ} \mathrm{C}$

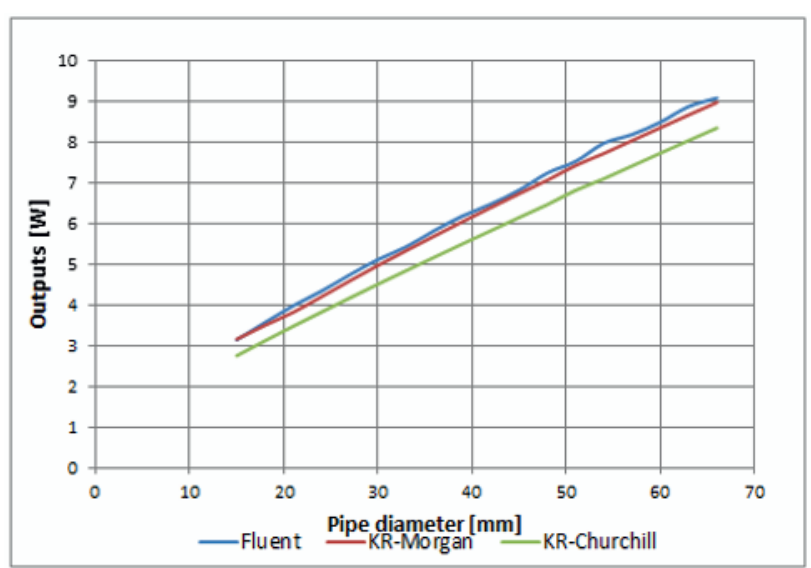


Graph 2. Heat output of horizontal pipe at natural convection at the temperature of pipe's wall $45^{\circ} \mathrm{C}$ and at the surrounding temperature $20^{\circ} \mathrm{C}$

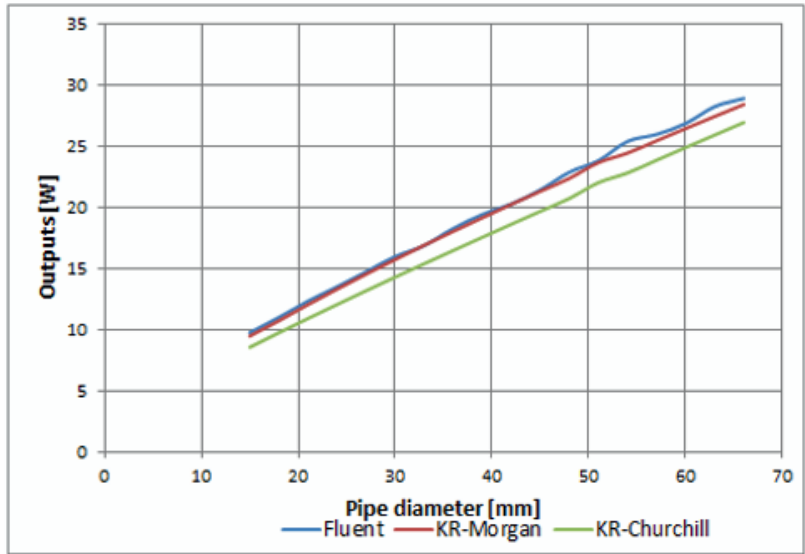

Graph 3. Heat output of horizontal pipe at natural convection at the temperature of pipe's wall $90^{\circ} \mathrm{C}$ and at the surrounding temperature $20^{\circ} \mathrm{C}$

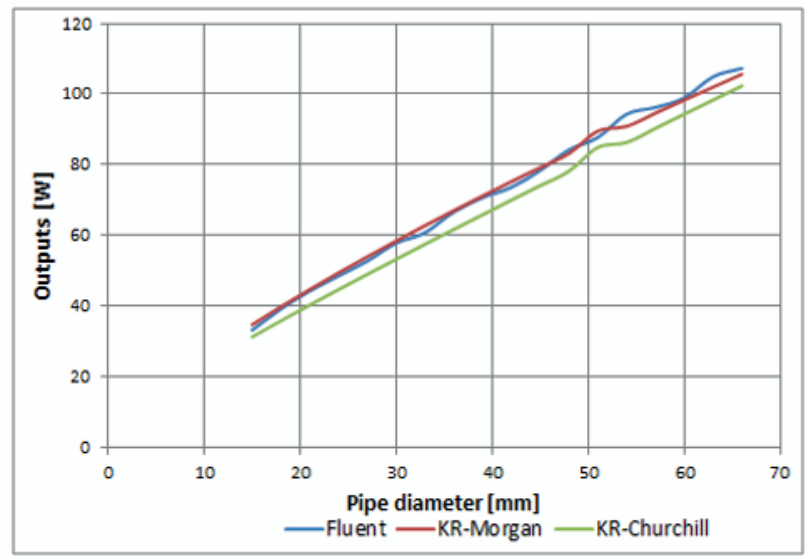

Graph 4. Heat output of horizontal pipe at natural convection at the temperature of pipe's wall $105^{\circ} \mathrm{C}$ and at the surrounding temperature $20^{\circ} \mathrm{C}$

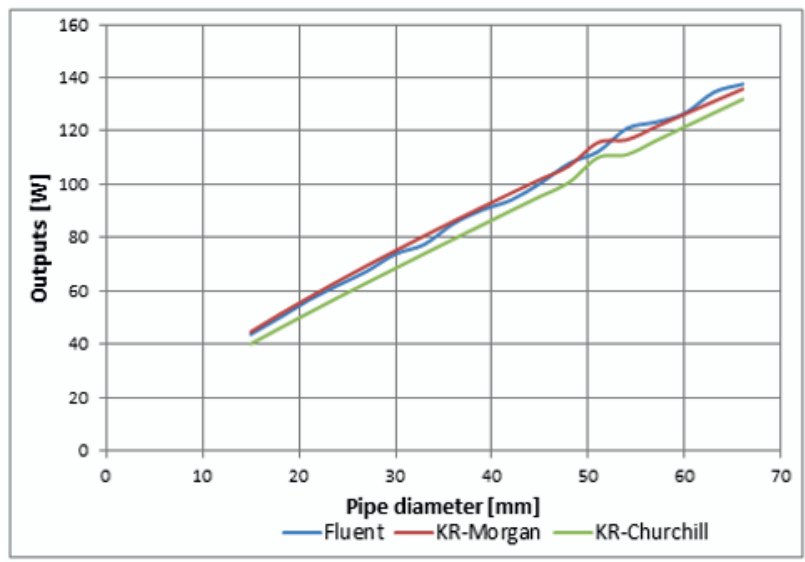

Relations of calculated heat output of horizontal pipe at natural convection are shown in following graphs (graph 1 to 4). In graphs are shown calculations with the help of programme Ansys-Fluent as well as on the basis of criterion equations.

\section{Summary}

Two already mentioned calculation relations of calculating Nusselt number were used to calculate heat output on the basis of criterion equations. From these graps is evident that to calculate heat output of horizontal pipe at natural convection from criterion equations the relation according to Morgan [1] corresponds with the calculation in the programe Ansys - Fluent better than the calculation of heat output using criterion equation according to Churchill. This closeness of output processes is evident in whole simulated range, it means by horizontal pipes with diameters $15 \mathrm{~mm}$ to $66 \mathrm{~mm}$ at a wall tempetarute $30^{\circ} \mathrm{C}, 45^{\circ} \mathrm{C}, 60^{\circ} \mathrm{C}, 75^{\circ} \mathrm{C}, 90^{\circ} \mathrm{C}, 105^{\circ} \mathrm{C}$ and at surrounding temperature $20^{\circ} \mathrm{C}$. As it is seen from these graphs and tables the differences of calculated heat outputs accordning to these two criterion relations are minimal, which can be caused by the fact that Churchill relation is given for whole range of Rayleigh number $10^{-5}<\operatorname{Rad}<10^{12}$ in contrast to Morgan relation which defines multiple relations in various ranges Rad.In the near future we want to creating a criterion equation for „n“ horizontal pipes one above another. On the basis of this comparison where equalities will be gained in calculated and modelled results, models will be created in the programme Ansys-Fluent for „n“ horizontal pipes one above another.

\section{Acknowledgements}

This paper is solved by VEGA project "Heat transfer from oriented heat exchange areas by natural convection" $1 / 1127 / 11$.

\section{References}

1. F.P. Incropera, D.P. Dewitt, T.L. Bergman, A. Lavine, Fund. of Heat and Mass Trans. 6 ed. (2007)

2. M.J. Moran, H.N. Shapiro, B.R. Munson, D.P. DeWitt, Intr. of Therm. Sys. Eng.: Thermodyn. (2003)

3. E. Kabát, Š. Horník, Prenos tepl. a látky (1993)

4. O.G. Martinenko, P.P. Khramtson, Free Conv. Heat Transf. (2005)

5. K. Patel, B.F. Armaly, T.S. Chen, Transition from Turb. Natural to Turb. F. Conv. Adj. to an Isotherm. Vert. Plate, Vol. 324, 55-56 (1996)

6. M.J. Latif, Heat Conv. (2006) 